\title{
Lumen
}

Selected Proceedings from the Canadian Society for Eighteenth-Century Studies

\section{Venanzio Rauzzini: An Italian Musician in Britain}

\section{Paul Rice}

Volume 33, 2014

URI : https://id.erudit.org/iderudit/1026567ar

DOI : https://doi.org/10.7202/1026567ar

Aller au sommaire du numéro

Éditeur(s)

Canadian Society for Eighteenth-Century Studies / Société canadienne d'étude du dix-huitième siècle

ISSN

1209-3696 (imprimé)

1927-8284 (numérique)

Découvrir la revue

Citer cet article

Rice, P. (2014). Venanzio Rauzzini: An Italian Musician in Britain. Lumen, 33 , 101-121. https://doi.org/10.7202/1026567ar d'utilisation que vous pouvez consulter en ligne.

https://apropos.erudit.org/fr/usagers/politique-dutilisation/ 


\title{
Venanzio Rauzzini: An Italian Musician in Britain
}

\author{
Paul Rice \\ Memorial University of Newfoundland
}

Venanzio Rauzzini (1746-1810) enjoyed a significant and varied musical career in Britain that lasted from 1774 until his death. During this time, he variously sang in Italian opera performances in London, composed instrumental and vocal music, directed a concert series in Bath for thirty years, and was one of the most respected singing teachers in Britain. As a foreigner, a Catholic and a castrato, Rauzzini was someone who was "other," both socially and physically. Unlike the visiting operatic castrati who preceded him, Rauzzini was the first castrato singer to make Britain his permanent home, rather than returning to the Continent after his performing days were over. ${ }^{1}$ That he would achieve a position of cultural leadership in Britain was both unprecedented and unexpected. In the process, he became a target of distrust and suspicion by those who could not envision a castrato in a leadership role. The implications of Rauzzini's varied career are considerable, and reveal how the changing social and political demographics of Britain affected not only how concert music was perceived by its audience, but also what music should be performed and by whom. This paper explores some of the resulting tensions experienced by Rauzzini during his British career, especially during the late years of

1. Patrick Barbier, The World of the Castrati: The History of an Extraordinary Operatic Phenomenon. trans. Margaret Crosland (London: Souvenir Press, 1996), 211. Rauzzini's friend and colleague, the castrato, Giusto Ferdinando Tenducci (1736-90), also spent much time in Britain after his debut in London in 1758. Tenducci, however, divided his time between the Continent and Britain, and died in Genoa in 1790. 
the eighteenth century, and the early years of the nineteenth when Britain was involved in the Napoleonic Wars.

\section{The King's Theatre Years}

Rauzzini came to Britain in 1774, after accepting a contract to sing the primo uomo roles in the $1774-75$ season of Italian operas at the King's Theatre in London. His pedigree as a singer was impressive. He made his operatic debut in Rome in 1765 , and quickly progressed to other theatres on the Italian peninsula before entering into the service of Elector Maximilian III in Munich in 1766. He remained in Munich until 1772, although he was given leave to perform in Venice and Vienna, where he enjoyed conspicuous success. ${ }^{2}$ Charles Burney heard Rauzzini in Munich when Burney visited there in 1772 . Burney was much impressed by the singer who was then only twenty-six years of age: "he is a charming performer; his taste is quite modern and delicate; the tone of his voice sweet and clear; his execution of passages of the most difficult intonation amazingly neat, rapid, and free: and his knowledge of harmony is far beyond that of any great stage-singer I ever knew: he is likewise a very good person, and, I am told, is an excellent actor."

One of Rauzzini's most significant Continental accomplishments was the creation of the role of Cecilio in Wolfgang Amadeus Mozart's opera, Lucio Silla, in Milan on 26 December 1772. The seventeenyear-old Wolfgang had waited to compose Rauzzini's arias until the singer was in the city, so that he could judge the singer's voice, and secure his approbation. One might imagine that even the young Mozart felt some slight trepidation when composing for a singer who was, himself, an established composer. The two young men appear to

2. A modern, critical biography of Rauzzini's Continental career is much needed. The most detailed account is to be found in Johannes Reindl, "Venanzio Rauzzini als Instumental-Komponist," (Ph. D. diss. U. of Vienna, 1961), 11-35. A study of Rauzzini's British career is in progress by the present author.

3. Charles Burney, The Present State of Music In Germany, the Netherlands, and United Provinces. Or, the journal of a tour through those counties, undertaken to collect materials for a general history of music . in two volumes. $2^{\text {nd }}$ edition. (London: 1775), I: 151. The first edition of Burney's observations on Continental music had been published in 1773, and his positive assessment of Rauzzini would have already been known prior to the singer's arrival in London. 
have developed a congenial working relationship, and Mozart's father, Leopold, wrote to his wife on 28 November that "Wolfgang has only composed the first aria for the primo uomo, ["Il tenero momento"] but it is superlatively beautiful and he sings it like an angel." Indeed, the younger Mozart was so pleased with Rauzzini's singing that he composed the exquisite motet, Exultate jubilate, for Rauzzini to perform in Milan's Church of San Antonio on 17 January 1773.

Whether or not Charles Burney had been consulted about Rauzzini as a potential primo uomo for the King's Theatre remains unconfirmed, although Frances Burney's journals reveal that the Burney family knew of Rauzzini's hiring by 20 February $17744^{5}$ The London contract offered Rauzzini more financial security than did the peripatetic existence of the travelling opera singer on the Continent. After a bumpy start in London because of a severe cold, he was quickly accepted by the London audience and praised by critics. That he remained with the company for two further seasons was exceptional for, as Susan Burney notes, "castrati quickly wore out their welcome in London and were not rehired." Rauzzini proved himself to be a significant addition to the company, being one of those rare singers whose acting was the equal of his singing. A letter by Edward Pigott records his visit to the theatre for a performance of the pasticcio opera, Didone (1775): "Rauzzini acted the part of Eneas, he is young, has an exceeding handsome face, he acts better than has yet been seen, Garrick says he never saw better, his Voice answers his figure and talents, being very strong, soft and sonorous, and sing[s] with surprising tast [sic]."?

4. Emily Anderson, ed. and trans., The Letters of Mozart and his Family, $2^{\text {nd }}$ ed. prepared by A. Hyatt King and Monica Carolan, 2 vols (London: MacMillan, 1966), I: 218 .

5. Frances Burney, The Early Journals and Letters of Fanny Burney, Ed. Lars E. Troide and Stewart J. Cooke, 4 vols. (Montreal \& Kingston: McGill-Queens University Press, 1994), II: 8.

6. British Library, Egerton MS 3691, fols. 114r-115v, also cited by Stephen A.Willier, "Gasparo Paccierotti in London: The 1779-1780 Season in Susanna Burney's 'Letter-Journal'," Studi Musicali, 29.2 (2000), 285.

7. Quoted by Ian Woodfield, Opera and Drama in Eighteenth-Century London: The King's Theatre, Garrick and the Business of Performance. Cambridge Studies in Opera, ed. Arthur Groos. (Cambridge: Cambridge University Press, 2001), 129. Both Michael Kelly and William Bingley also report on Garrick's praise for Rauzzini's performance of the role of Piramus in the singer's own opera, Piramo e Tisbe. William Bingley, Musical Biography; or, Memoirs of the Life and Writings of the most eminent Musical composers and Writers . . . 2 vols (London: Henry Colburn, 1814), II: 317. 
Although Rauzzini enjoyed many successes in London, he still faced some of the prejudice that had been current in London since the importation of Italian opera in the early years of the eighteenth century. Italian opera was late addition to British culture, and the art form had many institutionalized conventions by the time that it became established in London as something to be patronized largely by the aristocracy. Not the least of these conventions was the use of castrated men singing in the female range for the leading male roles. Throughout most of Continental Europe, the juxtaposition of the female (voice) and male (body) resulted in "seductive figures of idyllic, heroic youth" commanding the utmost respect in the seventeenth century. ${ }^{8}$ In Britain, however, there were many who feared the influence of Italian art forms and the seductive power of the castrato voice.

Early negative commentary came from John Dennis (1658-1734) in an Essay on the Opera's after the Italian Manner . . with some Reflections on the Damage which they may bring to the Publick (1706), and An Essay Upon Publick Spirit (1711). ${ }^{9}$ For Dennis, Italian opera had several strikes against it. Firstly, it originated in a land that was tainted by Catholic dogma, and that was generally assumed to be the home of sodomy. Secondly, its leading male singers were eunuchs, who compromised traditional gender roles. Todd S. Gilman writes that castratos "transgressed a normative gender and sexuality at once insofar as their feminine beauty, cultivated deportment, and sirens' voices were believed capable of turning men into sodomites and because their popularity among the fair sex rendered them more sexually viable and thus more virile than British men." 10 The fear of possible religious contamination was also another concern. The anonymous author of Do you know what you are about? Or, A Protestant Alarm to Great Britain proposed that Parliament should ban the singing in

Michael Kelly, Reminiscences of Michael Kelly of the King's Theatre and Theatre Royal Drury Lane, ed. and with an introduction by A. Hyatt King. 2 vols (New York: Da Capo Press, 1968), I: 5.

8. Martha Feldman, Opera and Sovereignty: Transforming Myths in Eighteenthcentury Italy. (Chicago: University of Chicago Press, 2007), 365.

9. Both essays are found in The Critical Works of John Dennis, ed. Edward Niles Hooker (Baltimore: John Hopkins University Press, 1943).

10. Todd S. Gilman, “The Italian (Castrato) in London," in The Work of Opera: Genre, Nationhood, and Sexual Difference, ed. Richard Dellamora and Daniel Fischlin (New York: Columbia University Press, 1997), 50. 
foreign languages so that no possible "evil" influence could infiltrate the British psyche: "Who knows, but under Colour of an Opera, they may sing Mass as they have done before; witness, A Hymn to the Virgin. Written by Cardinal Coscia, and sung by Signora Catsoni to a Harp, in the Opera of Julius Ccesar."

Roger Freitas provides some insight into these irrational fears. Fundamentally, the castrati were perceived as threats to the family unit and traditional male sexual domination, rather than harmless androgynous creatures to be pitied or mocked. This was a result of the castrato achieving a status that "normal" men could not hope to equal, let alone surpass. Freitas writes that "the castrato represented not a neutral vessel for an exotic sound, but rather an alluring figure whose talent only augmented an innate desirability. Castrati thus played amorous leading roles not in spite of their physical distinctiveness, but because of it." 12 Freitas further writes that the castrato opera singer became a "super-natural manifestation of a widely-held erotic ideal" and the "spectacularly exaggerated embodiment of the ideal lover." 13 These singers may have represented idealized visions for women, but they were visions that "normal" males could not emulate. Consequently, the adulation given to castrati by women was viewed as dislocating the accepted norms of society, and threatening the traditional social discourse between men and women.

Rauzzini's good looks and strong acting abilities encouraged this kind of paranoia. Prior to the beginning of his third season with the King's Theatre, the following notice appeared in the Morning Post:

Signor Rauzzini we are assured, owes his continuance in this kingdom to the interposition of several married ladies of the first rank, who made it a point with the managers of the opera-house, that he should positively be engaged, or they would withdraw their subscriptions: It seems many of these illustrious females are enamoured with this semblance of manhood, and to such a pitch of phrenzy [sic], that they cannot exist without him! but what is still more surprising, some of these love sick ladies have men for their husbands, who as men, do honour to their species." 14

11. Anon. Do you know what you are about? Or, A Protestant Alarm to Great Britain. (London: 1733), [iii].

12. Roger Freitas, "The Eroticism of Emasculation: Confronting the Baroque Body of the Castrato," Journal of Musicology 20 no. 2 (Spring 2003), 202.

13. Ibid., 249.

14. Morning Post, 19 August 1776, 3 . 
Not only did this notice continue earlier tropes about the negative influence of the castrato voice, it denigrates Rauzzini personally as being a mere "semblance" of a man, while suggesting that his engagement for a third year was the result of blackmail tactics from frenzied females. Such tropes about the dangers of the castrato voice were easily transferable, and the same newspaper mounted a similar attack on Francesco Roncaglia (c. 1750 - after 1812), Rauzzini's successor at the King's Theatre. The newspaper announced Roncaglia's arrival in London, but with comments that continue the earlier innuendos made against Rauzzini: "Signor Roncaglia, the new serious opera singer who succeeds Rauzzini, is said to be the most beautiful being that ever was created; he is just arrived, and several women of the most acknowledged gusto have already had specimens of his abilities, and declare his powers transcend even those of their late love-inspiring castrato!"15

Whether or not these reports in the Morning Post are true is open to question. Phrases such as "we are assured" and "is said to be" clearly denote the repetition of gossip, thus confirming Lucyle Werkmeister's assertion that the "Post had inaugurated the age of the scandal sheet."16 The newspaper had first appeared on 2 November 1772, with the original proprietors being Reverend Henry Bate, Reverend John Trussler and Mr. John Bell. The newspaper was markedly different in its interests from other London papers in that it dealt as much with entertainment (books, theatrical presentations, auctions and domestic issues etc.) as it did with politics. Henry Bate, as editor, went out of his way to court controversy, and even indulged in much publicized duels. At the same time, the paper was known to be pro-Government. ${ }^{17}$ As a result, Henry Bate was able to continue the rhetoric about the dangers of the castrato voice, wrapping such concerns in a cachet of morality and patriotism, while at the same time furthering his own agenda of creating the kind of controversy that titillated his readership.

The fears surrounding the castrato voice followed Rauzzini outside of the opera house. The focus on his altered physiognomy diverted attention away from the singer's artistry, even in concert performances.

15. Morning Post, 28 October 1777, 2.

16. Lucyle Werkmeister, A Newspaper History of England: 1792-1793 (Lincoln NB: University of Nebraska Press, 1967), 35 .

17. Lucyle Werkmeister, The London Daily Press: 1772-1792 (Lincoln NB: University of Nebraska Press, 1963), 20-34. 
Edmund Rack attended a concert in Bath in 1779 when Rauzzini was the featured soloist. He writes that "Rauzina [sic] is a eunich \& has a fine shrill pipe, but I dont admire these shreds of men, shells of human beings." 18 When Rauzzini performed in Handel's Messiah and Judas Maccabceus in Bristol in March of 1782 , he was joined by the celebrated castrato, Giusto Ferdinando Tenducci. The singers were accorded a poor reception by an audience not used to the castrato voice. The Morning Herald and Daily Advertiser reported that "the poor Signiors encountered a world of mortifications; the rude Bristolians, uncorrupted by the vicious taste of the times, looked upon them as objects of ridicule rather than admiration." 19 That the newspaper refers to the taste for castrato singing as a "corruption" and a "vicious taste" is highly telling. Anthony Fletcher writes about British attitudes to gender, stating that it was "important to ensure that gender provided a respected foundational structure which could make sense of each person's identity and enable society to function without disorder." 20 The nature of the castrato voice undermined a clear gender identity, and seemingly invited social disorder.

After three seasons of opera, Rauzzini decided to change his career direction. He was still singing well, and presumably could have returned to Italy to continue his operatic career had he wished. Instead, he increased his compositional output, and published string quartets and sonatas for piano and violin, in addition to vocal repertoire. He also became involved in concert management with the violinist, Franz La Motte, with whom he created concert series in both London and Bath. Rauzzini and La Motte walked into a fraught situation when they journeyed to Bath in 1777. Mr. Gyde, the manager of the Lower Assembly Rooms had wanted to attract the aristocratic and wealthy visitors who previously had flocked to the concerts presented by Thomas Linley Sr. in the more fashionable New (or Upper) Assembly

18. Rack's journal consists of a series of letters sent to his relatives between 22 December 1779 and 22 March 1780. The manuscript is held at the Bath Central Library (MS. 1111). The letters have been transcribed and edited by Trevor Fawcett, and published by the Bath Archives.

http://www.batharchives.co.uk/explore_the_archives/the_journal_of_edmund_ rack.aspx

19. The Morning Herald and Daily Advertiser, 3 April 1782, 4.

20. Anthony Fletcher, Gender, Sex and Subordination in England: 1500-1800 (New Haven: Yale University Press, 1995), 83. 
Rooms. Linley had been absent during the previous autumn, however, and the concerts in the Upper Rooms had lost some of their earlier prestige. Linley never re-established himself in Bath, and La Motte and Rauzzini transferred their concerts to the Upper Rooms the following year. The two men shared the direction of the series until La Motte's death in 1780 , at which time Rauzzini left London and focused his attention on the Bath concerts. ${ }^{21}$ This was likely a well-considered decision on Rauzzini's part. After London, Bath could lay claim to being the most artistically important city in Britain.

\section{The Bath Years}

Bath was one of the most important stops for the wealthy in the yearly rounds between their various metropolitan homes and country estates. Bath had long enjoyed its reputation as a spa town where the alleged healing properties of the mineral waters were famous. Readers of Jane Austen will know that, socially, the "Bath Season" had become an opportunity to present young ladies of marriageable age to society, with the hope of a suitable betrothal resulting. These visitors were known as the "Company," and Bath was largely dependent on the visits of the "Company" for its financial survival. Franz Joseph Haydn visited Bath in 1794 and he left the following account: "The city is not thickly populated, and in Summer one sees very few people; for the people taking the baths don't come till the beginning of October, and stay through half of February. But then a great many people come, so that in the year 1791, 25,000 persons were there. All the inhabitants live off this influx, without which the city would be very poor; there are very few merchants and almost no trade, and everything is very dear." 22 Not all of the "Company" stayed quite as long as Haydn indicates, and by mid-January, many had already moved on, most often to London.

While the "Company" was in Bath, it was necessary to keep them entertained, and balls, plays and concerts were presented. The length of stay for members of the "Company" varied from a couple of weeks to several months, depending upon the wealth of the individuals, and

21. Kenneth James, "Concert Life in Eighteenth-Century Bath," (Ph. D. diss., Royal Holloway College, University of London, 1987), 214-16.

22. H.C. Robbins Landon, Haydn: A Documentary Study (New York: Rizzoli, $1981), 142-43$. 
their obligations elsewhere. Because some of the influential members of this transient population stayed for several months, it was necessary to ensure that there was a constant supply of new entertainments in the city. The following outlines the schedule of entertainments:

Monday: Dress Ball, Upper Rooms.

Tuesday: Cotillion Ball, Lower Rooms, - Theatre Royal.

Wednesday: Subscription Concert, Upper Rooms.

Thursday: Cotillion Ball, Upper Rooms, - Theatre Royal.

Friday: Dress Ball, Lower Rooms - Catch Club, White Hart Tavern.

Saturday: Theatre Royal. ${ }^{23}$

\section{The Bath Concerts}

Rauzzini's subscription concerts quickly became a highlight of the Bath schedule of entertainments. These concerts were presented on Wednesday evenings in the Upper Assembly Rooms, the elegant facility that had been completed in 1771in the exclusive "New Town" area of Bath. Rauzzini mounted up to twelve subscription concerts during the fall and early winter months each year. The initial concerts were often presented in the smaller Tea Room in late November, later moving to the Ball Room when the audience numbers increased. The Ball Room was the largest Georgian interior in Bath, and newspaper reports speak of over 1000 people in attendance at various times during Rauzzini's career. ${ }^{24} \mathrm{~A}$ second subscription of two or three concerts over the Easter season might be offered, if there was sufficient demand. The subscription concerts became an integral part of the complex social fabric of the "Bath Season," and Rauzzini remained their director until his death in 1810 . As important as the concert series was to the continued financial success of the city, it was Rauzzini who held full financial liability. It was important that he appeal to the tastes of the influential

23. John A. Gillaspie, The Catalogue of Music in the Bath Reference Library to 1985. 4 vols (London: K.C. Saur, 1986), I: xxv.

24. Although damaged during WW II, the Assembly Rooms reopened in 1963 . The occupancy limit of the grand ball room is currently set at 500. Doubling that number during the eighteenth century must have resulted in considerable discomfort. The spaces at the Assembly Rooms are described in greater detail in Mowbray A. Green, The Eighteenth Century Architecture of Bath, 2 vols. (Bath: George Gregory, 1904), II: 159-64. Modern photographs and descriptions can be found at http://www.bathvenues.co.uk/assembly_rooms.aspx 
"Company" in his programming of repertoire and his choice of soloists. This was the same audience demographic that frequented the prestigious subscription series in London run by J.C. Bach (1735-82) and K.F. Abel (1723-87), where the repertoire was largely that of Continental composers. Many would have also frequented the performances of Italian operas at the King's Theatre. It is not surprising, therefore, that Rauzzini's concerts similarly featured music by Continental composers, often performed by foreign "star" soloists, both vocal and instrumental.

Given the amount of interest in recent years in the concert life of eighteenth-century Britain, it is surprising that Rauzzini's Bath concerts have been so little studied. ${ }^{25}$ Kenneth James' examination of the concert life in eighteenth-century Bath encompasses all aspects of the musical life there, yet does not examine the repertoire of Rauzzini's concerts in great detail. The real scope of Rauzzini's accomplishments with his Bath concerts is only revealed when the listings of the repertoire are compiled. ${ }^{26}$ Partly this can be explained by the fact that it was not until the mid-178os that Rauzzini began to publish regularly in the various Bath newspapers the programmes to be performed. Often, he chose one newspaper to print the full programme, while the other newspapers might carry a notice of the concert, but without the repertoire to be given. This practice of partial notification can result in gaps in our knowledge of what was performed when print runs of a particular newspaper have not survived. ${ }^{27}$ The printed concert handbills are likely the most authoritative sources since they were printed immediately prior to the concert. Unfortunately, few of these have survived. Typical of newspaper advertisements of the period, compositions were

25. Simon McVeigh's Concert life in London from Mozart to Haydn (Cambridge: Cambridge University Press, 1993), and Concert Life in Eighteenth-Century Britain, Eds. Susan Wollenberg and Simon McVeigh (Burlington, VT: Ashgate, 2004) are significant studies, although it is remarkable that the latter book makes but fleeting mention of the Bath concerts.

26. This has proved to be an onerous, albeit rewarding, task and will be a part of my forthcoming study of Rauzzini's British career.

27. In the period beginning inıoo, Rauzzini advertised with the Bath Herald. Regrettably, only sporadic copies of this newspaper have survived for the period of 1800-1802. The Bath Library and Information Centre (The Podium) has original copies thereafter that have not been microfilmed. It should also be remembered that what was performed in the concerts was sometimes different from what was advertised in the newspapers. 
usually not identified by name. As a result, the composer of a symphony, overture, concerto or song might be given, along with the performer's name, but not the actual title of the work.

Until the 1790-91 season, Rauzzini presented his concert programmes in two "Acts," with the first offering modern music: songs, concerti and orchestral music. The second Act presented "Ancient Music," most often by Handel, although Rauzzini sometimes programmed concerti grossi by Corelli, and music by other early composers as well. None of the music in the second Act was particularly old. The difference was one of musical style-baroque versus classical. Given that some of the concert societies in London were devoted exclusively to the performance of either modern music or earlier music, Rauzzini may have been attempting to accommodate as many musical tastes as possible. ${ }^{28}$ At the same time, the popularity of Handel's music remained undiminished in Britain, and Rauzzini would have been foolish not to capitalize on that popularity. As the programme from the opening of the 1786 season demonstrates, the up-to-date Viennese classicism was represented in the first Act by a Haydn symphony and a Mozart piano concerto. The names of the performers, as found in the newspaper advertisement in the Bath Chronicle and Weekly Gazette (9 November 1786), have been added below in parentheses:

15 November 1786

Act I: Haydn: Symphony No. 73 in D major, "La Chasse;" Sacchini: Unspecified Song (Maria Poole); Unspecified Flute Concerto (Tebaldo Monzani); Prati: Rondo (Marie Chanu); Unspecified Violin Concerto (Diedonné Pascal Pieltain); Guglielmi: Unspecified Song (Ann Cantello); Mozart: Unspecified Piano Concerto (Johann Cramer, Junior).

Act II: Handel. Overture to Esther; The Funeral Anthem as it was performed at Westminster Abbey; The Dead March in Saul; Acis and Galatea: "Hush, ye pretty warbling Quire" (Marie Chanu); Chorus, Jephtha: "Cherub and Seraphim" Radamisto: "Cara sposo amato bene" (Ann Cantelo); Coronation Anthem: Zadok the Priest.

After the 1790-91 season, Rauzzini most often presented mixed concerts with largely modern music, and restricted the performance of

28. For the 1789-90 season in London, Simon McVeigh lists the Professional Concert and the Pantheon Grand Concert as presenting modern music, while the Concert of Ancient Music, the Academy of Ancient music and the Handel Festival presented earlier music. Concert life in London from Mozart to Haydn, 5. 
earlier music to three choral evenings, during which the music of Handel predominated.

Whenever possible, Rauzzini engaged singers from the King's Opera House in London as a "hook" to encourage people to buy the subscription. The occasional guest appearances of Nancy Storace, Gertrude Elizabeth Mara, and in later years, Angelica Catalani, were much anticipated. On the other nights, British singers such as Ann Cantelo, Miss Storer and Marie Chanu provided yeoman service. Although the success of the series depended upon the soloists, they were not paid for their performances until 1795. Prior to this date, they depended upon the proceeds of a benefit night as their reward. J.C. Fischer was one of the most famous oboists of the day, and a great favourite in both Bath and London. An advertisement in the Bath Journal for Fischer's benefit concert in 1780 states: "Mr. Fischer [has] no Emolument whatever for his Performance at the concerts, but what he derives from his Benefit, tho' generally considered as their chief support." ${ }^{29}$ This pointed comment suggests that, should his audience desert him, Fischer might not return in the future. The system of benefit evenings was a common practice in both the musical and theatrical worlds, although it was usually an opportunity given to principal actors and singers to augment their negotiated salaries. In the Bath concerts, the single benefit night was the only way for soloists to earn their keep. The results could be unpredictable, and Fischer's final benefit concert on 4 January 1786 was poorly attended because of a storm. The Bath Journal and the Bath Chronicle reported that he was forced to repeat the concert at noon on the following Saturday in order to recoup his losses.

Scheduling the benefit evenings was a matter often requiring some diplomacy because the more prestigious soloists were given benefit concerts on evenings earlier in the season than were the more junior soloists. A benefit concert held before Christmas stood a better chance of attracting a larger audience than one in late January, a time when many of the "Company" were preparing to leave Bath. Given that the more junior soloists were often British-born, whilst the "star" soloists were frequently foreign-born, it could appear as if the junior soloists were second-class citizens in their own country

29. Bath Journal, 20 December 1780, 3. 
who were being denied the opportunity to obtain a profitable benefit evening. Further complicating the situation was that the big name foreign soloists sometimes declined to participate in these concerts or arranged to be elsewhere. Miss Storer's benefit concert in 1783 was the last of the season, and lacked the "star" power of foreign names. The Bath Journal proudly trumpeted the success of this concert, even without the presence of the big names: "Though neither the names of Tenducci, Rauzzini, Fischer, nor Guest graced the orchestra, there were upwards of 500 persons present-which clearly evinces that the people of fashion frequenting Bath when they meet with superior merit tho' the product of their own clime, will reward it tho' unassisted by foreign attractions." ${ }^{30}$ The complaint that British-born musicians were treated as if they were subordinate to Continental "star" soloists was hardly a new one, especially in London. ${ }^{31}$ What is remarkable about the review in the Bath Journal is that it not only makes a case for Miss Storer's accomplishments, but it also suggests that there had been a shift in the perceptions of the audience so that her accomplishments could be fully recognized.

The financial success of the concert series was dependent upon the visiting "Company," a group that began to abandon Bath during the politically unstable years of 1792-95. At the conclusion of the 1793-94 season, the Bath Chronicle reported: "We regret exceedingly to learn that the subscription to the Concerts, which are not surpassed in this kingdom for judicious selection and performance, has fallen so short this season, that their worthy conductor RAUZZINI will be a great loser by them." 32 Bath was very empty of the "Company" during the 1794-95 season, and a second benefit concert was planned for Rauzzini on 8 April 1795. It appears to have been much needed. At the time that this concert was advertised, Rauzzini released a statement stating that the this would be his last concert "as Manager and Director of the Subscription Concerts," because past financial losses and the difficulty of securing performers of the first rank made their continuance

30. Bath Journal, 14 April 1783, 3.

31. As Simon McVeigh has noted, "for all but the foreign élite, entry into London's concert life was achieved only by arduous struggle; and for most musicians the struggle for material prosperity and for advancement within the profession continued to the end of their lives." Concert life in London from Mozart to Haydn, 182.

32. Bath Chronicle, 13 February 1794, 3. 
untenable "unless a plan [could] be suggested to prevent his being a loser in the future." 33 The spectre of Bath without its concert series was a serious challenge to the traditions of the Bath "Season," and a committee under the direction of Sir George Colebrooke was formed to take over the management of the concerts for a year. This committee inaugurated some changes in the organization of the series and undertook to underwrite any losses for that season. Thereafter, Rauzzini once again assumed full financial responsibility.

One of the changes introduced by Colebrooke's committee was the reduction of the subscription concerts to nine, which were supplemented by three "Choral Nights" that were outside of the subscription and cost extra. While these choral evenings were initially popular, audience attendance soon began to wane. During the 1797-98 season, Rauzzini published statements that he could only continue the concert series if the "Choral Nights" were patronized. ${ }^{34}$ This did not transpire, and the choral evenings were absorbed into the general subscription for the 1798-99 season. As a result, the cost of the subscription increased accordingly. Rauzzini was ambitious in his programming, and on 10 December 1800 , he presented Haydn's oratorio, The Creation. On 12 January 1803 , he performed Haydn's The Seasons. This was less than two years after the premiere of the work in Vienna, on 24 April 1801. Rauzzini attempted to be as up-to-date as possible in his repertoire choices. Beginning on 23 November 1803, he began programming symphonies by Beethoven, boldly advertising that the performance materials were manuscript, rather than published. In addition to works by Haydn, Mozart and Beethoven, Rauzzini programmed music by Luigi Cherubini, Franz Krommer, and possibly Carl Maria von Weber. ${ }^{35}$ Examination of the repertoire performed in the 1790 s and in the first decade of the nineteenth century demonstrates that Rauzzini's repertoire choices were as progressive as those of the finest concert series in London.

33. Bath Chronicle, (2 April 1795), 3.

34. Bath Journal, (11 December 1797), 3.

35. On 4 January 1809, the newspaper advertisements list a new overture by Weber. Whether the reference was to Bedřich Diviš Weber (1766-1842), Edmund Weber (1766-1813), Franz Anton von Weber (1734-1812) or Carl Maria von Weber (1786-1826) is not clear. It possible that Rauzzini had obtained a copy of Carl Maria von Weber's Grande Overture à plusieurs instruments that had been published in parts in 1807 . 
In spite of Rauzzini's flair for programming, the fortunes of the concert series varied considerably during the first decade of the nineteenth century. Rauzzini was forced to cut expenditures during the 1807-1808 season by reducing the number of concerts from twelve to nine, and presenting only two choral evenings. It would appear that Rauzzini was not able to make a consistent profit from the concerts, and that he had to rely upon teaching for his principal income. One might question why Rauzzini would have continued on with the concert series when it was financially precarious to do so. There is little doubt that Rauzzini was dedicated to preserving high musical standards in his concerts and that he enjoyed working with the illustrious visiting soloists. When matters looked particularly bleak for him in Bath following the death of La Motte in 1780, Rauzzini was encouraged by his fellow castrato, Gasparo Pacchierotti (1740-1821), to return to Italy and take up an active performing career in opera. Susan Burney records Pacchierotti's account of Rauzzini's response: “But he said to Me He had established here a Concert, \& he must now endeavour to support it-but I am afraid indeed it will not answer- \& I am very sorry, as he is indeed a very good natured young Man." ${ }^{36}$ This was likely true in 1780 , but altruism on this level was likely not the only reason why Rauzzini struggled on with the concert series as a speculative venture until his death in 1810 . Indeed, during his later years in Bath, the concerts existed in a symbiotic relationship with Rauzzini's teaching studio, and it was from teaching that Rauzzini appears to have gained the largest part of his income.

\section{Rauzzini as Pedagogue}

Rauzzini had quickly established a reputation as vocal pedagogue after his debut in London in 1774. The prima donna chosen by the theatre for that season was his former student, Caterina Schinderlin. Her voice was likely too small for a large theatre, and Charles Burney found her to be "coquettish, silly, and insipid." ${ }^{37}$ At the same time, there was little doubt that her method was correct since she survived a complete season of serious operas at the King's Theatre, and maintained a career

36. British Library: Egerton Ms. 3691. fol. 66v. Letter written on 19 January [1780].

37. Charles Burney, A General History of Music from the Earliest Ages to the Present Period. 4 Vols. (London: Printed for the author, 1776-89), IV: 501. 
on the Continent thereafter. Teaching continued to be an important aspect of Rauzzini's life after he settled in Bath. The most promising of the young students who hoped for a professional career were taken on as apprentices. They appeared in the concerts as assisting artists, gradually moving up to singing more difficult music. While they were apprentices, Rauzzini did not have to pay them for their performances, although it is recorded that he sometimes did pay those who were in financial need..$^{38}$ These apprentices not only benefitted from excellent vocal training, but they also gained experience in singing with an orchestra, and were exposed to audience members who were in a position to help their future career aspirations. Some of the leading singers in Britain began their careers as Rauzzini's apprentices, including Charles Incledon, John Braham, Jonathan Nield, and Maria Poole. Their subsequent fame as singers served to enhance Rauzzini’s fame as a pedagogue.

There was another group of students who did not aspire to become professional singers, but who were crucial to Rauzzini's financial security. These were genteel young ladies for whom the ability to perform music well was a valued accomplishment that enhanced their attractiveness in the elaborate courtship rituals that were a part of the social discourse of Bath. Teaching these students had the potential to be lucrative for Rauzzini. In a letter written to her mother on 4 January 1793, Elizabeth Canning describes a private concert that she had attended where a Miss Gubbins sang, accompanied by Rauzzini: "She is not a Linley, but her voice is very fine, \& I could not but envy her. I asked her sister how long she had been taught by $\mathrm{M}^{\mathrm{r}}$ Rautzini [sic], the reply was "Oh she has not had much instruction, about a hundred [and] fifty Lessons." ${ }^{39}$ While we do not know how much Rauzzini charged per lesson, it would seem that the opportunity was there to make a considerable income from this type of teaching. As the same time, it invited the charge of avarice. In January of 1785 , an editorial critical of Rauzzini found its way into several London newspapers that painted Rauzzini in a negative light: "Rauzzini is to live through the

38. John Britton, The History and Antiquities of Bath Abbey Church, including Biographical Anecdotes of the Most Distinguished Persons Interred in that Edifice: with an Essay on Epigraphs, in which its Principal Monumental Inscriptions are Recorded (London: Longman and Co., 1825), 117.

39. Quoted by John Gillaspie, op. cit., I: 350 . 
winter on the clouted cream and other good fare of the Bath market ... which shews the Bath waters are not sovereign in ear infirmities-And so-Rauzzini for their money." 40

\section{Years of Challenge}

Nevertheless, the mid-179os proved to be an especially difficult time for Rauzzini. Depictions of the French enemy as being of a "new kind" who attempted to "dissolve Society" and to "extirpate all Religion"41 created an atmosphere of uncertainty that fed any xenophobic tendencies in the land, and encouraged distrust of those who were difficult to categorize. Rauzzini was the first castrato to achieve a position of leadership in the country. In times of general stress, his status of being "other" socially appears to have reawakened some of the old fears about the negative influence of the castrato on society. In 1794, a controversy arose over his scheduling of performances of Handel's Messiah. Rauzzini had presented the oratorio for his own yearly benefit night (Christmas Eve) for many years, and he often gave another performance during Passion Week. In 1794, Rauzzini applied for permission to present the oratorio in the Bath Abbey, as he had done in past years. He was denied this time "unless he would consent to give one the next day for the profit of the Sunday Schools." ${ }^{\prime 2}$ This demand came from the Committee of Gentlemen who managed the Sunday Schools Charity, a group who did not understand that consecutive performances of the oratorio were impractical financially, especially when the audience base at that time of year was reduced in size. Since Rauzzini would have to pay the musicians for both performances, this proposal, if implemented, was bound to be a financial failure for him. He countered with an offer to give a performance of the oratorio either before or after the Holy week as a benefit for the Sunday Schools Charity. This was still a risky plan, but it would have given him access to the Bath Abbey for his own concert. This offer was refused, and

40. The Public Advertiser, 8 January 1785, 2, and The Gazetteer and New Daily Advertiser, 10 January 1785,3 .

41. Anon. Objections to the War Examined and Refuted by a Friend of Peace (London, 1793), 3; quoted by Clive Emsley in "Revolution, war and the nation state: the British and French experiences: 1789-1801." The French Revolution and British Popular Politics, ed. Mark Philp (Cambridge: Cambridge University Press, 1991), 103.

42. Bath Chronicle, 27 March 1794, 3. 
Rauzzini then resolved to give four concerts in the Upper Rooms, as opposed to the previously announced three concerts. Accordingly, he gave notice to the orchestra and singers that they were officially engaged. The added date was the Wednesday of Passion week, and it might appear that the decision had been made in a fit of pique. At the same time, he likely needed to add the extra performance since the Assembly Rooms did not seat as many people as the Abbey. The organizers of the Charity arranged for their concert in the Abbey on the same Wednesday, but at noon. They may have thought that they had avoided Rauzzini's concert in the process, but Rauzzini had scheduled a rehearsal for that time, and his musicians were thus not available. A Holy War resulted, with the Gentlemen of the Committee for the charity being outraged.

A very public debate raged in the Bath newspapers for several weeks. Rauzzini was accused of lying and "engrossing the whole Musick in Passion week to himself" by the Committee of Sunday Schools. Furthermore, they stated that "the cause of religion and morality will never be suffered to fall a sacrifice to that of luxury and dissipation." ${ }^{23}$ Not only did these comments attack Rauzzini's character, the comment about "dissipation" evokes the age-old fears about the spread of Catholicism and sodomy at the hands of the castrati. A damaging rift in the musical community of Bath soon developed, and the matter was put before a review committee of leading members of the city. The Bath Chronicle reported that "the misunderstanding between the Gentlemen of the committee of Sunday Schools and Mr. Rauzzini, having been submitted to several respectable Gentlemen, we have pleasure to hear, is in a way of being settled to general satisfaction." "44 Just how this resolution had been achieved is not recorded, and the comments were likely intended to give reassurance to the public that all was well again with the musical life in Bath. It would be difficult to believe, however, that hard feelings did not linger in the community for some time thereafter.

Rauzzini's training and performance career had centred on the traditions of Italian opera. He had taken care in his Bath concerts to present the most up-to-date music from the Continent, but in balanced

43. Bath Chronicle, 17 April 1794, 3.

44. Bath Chronicle, 24 April 1794, 3. 
programmes that contained earlier music, especially by Handel. Although earlier reviews had praised Rauzzini's repertoire choices and his well-polished performances, a new critical trope emerged in 1798 that reflects the changing social demographic of Bath society (away from the aristocracy, to the genteel, "middle class") and a fear of the perceived negative influence of Continental culture during a time of war. The Bath Chronicle published a review that called for an increase in simple, British songs in Rauzzini's concerts, along with a condemnation of the florid Italian school of singing:

Miss Comer's melodious tones gave additional charms to the popular ballad of "Mary's Dream."-Perhaps the more frequent introduction of these simple and affecting airs would be far from displeasing to the majority of the audience. The elaborate beauties of Italian composition may delight the chosen few, the adepts in musical science, but "they are caviare to the multitude," whose attention must be gained by an appeal to their feelings rather than to their taste. The complicated and difficult execution of the foreign school can only exact the cold applause of the judgement; but it is the province of the simple, intelligible, and pathetic harmony of the Scotch and English ballad, to seize irresistibly on the imagination, and deeply interest the heart. ${ }^{45}$

Given that the concert under review had included the prodigious talents of Gertrude Elizabeth Mara (who sang compositions that had been calculated to display the compass of her voice and her "scientific execution"), the reviewer challenged the traditional identity of the Bath subscription concerts, with a call to make them more like the popular programmes heard in the various pleasure gardens of London. The demand for more British content was echoed by letters found in the Bath Herald, one of which wished for the "gratifying consideration to the true English taste, that all the singers, and all their songs were of the pure English School." ${ }^{6}$ This demand represents a paradigm shift in the traditions of the Bath concerts. Whereas Continental music, and Italian vocal music in particular, had dominated the concert programmes previously, Rauzzini was now forced to introduce English-language repertoire such as partsongs, glees and ballads. This repertoire was in stark contrast stylistically to the Italian concert and

45. Bath Chronicle, 11 January 1798, 3.

46. Bath Herald, 24 November 1798, 3. 
opera arias that had been the focal point of the previous twenty years of his programming. In part, this demand for English-language music appears to emanate from the patriotic zeal of a country at war. National fervour never reached the hysterical levels in Britain as it did in France during the protracted war. ${ }^{47}$ At the same time, to have been perceived as being unpatriotic would have been completely untenable for Rauzzini in his position of concert director. He skilfully created the public perception of his being an ardent patriot who supported his adopted country. Rauzzini was able to create this perception through music in two ways.

Firstly, he programmed music that focussed on themes that spoke to the concerns of a country at war. On 14 December 1803, Rauzzini programmed extended excerpts from Handel's Judas Maccabeus for his first choral evening of the season. Many of the selections had texts that dealt with aspects of liberty, a concept close to Britons during the time of the Napoleonic wars. The patriotic emphasis in the concert did not go unnoticed by the critic of the Bath Herald who wrote that the choice of music from Judas Maccabeus had been particularly apt when "British patriotism and valour are summoned to the defense of everything." 48

Secondly, Rauzzini composed several topical pieces that responded to events in the war, thereby affirming his loyalties. One such example was his Dirge for Lord Nelson, first heard in Bath on 20 November 1805, less than a month after Nelson's death on 21 October. Rauzzini's dirge appears to have captured the intense sadness that the country felt when they learned of Nelson's loss. The Bath Journal considered the new work to have been the principal attraction of the concert: "a composition full of the most sublime effect, and which was heightened by the unexpected display of a beautiful Transparency of the much lamented Hero, executed in an admirable style by the ingenious Mr. Herbert." ${ }^{\prime 9}$ When the work was repeated at the concert of 27 November, the same paper commented that the composition "drew tears of grateful sensibility from many for our fallen hero." ${ }^{\circ 0}$ The Dirge was also appreciated outside of Bath, and was heard "with the greatest applause," when it

47. Emsley, op. cit., 109 .

48. Bath Herald, 17 December $1803,3$.

49. Bath Journal, 25 November $1805,3$.

50. Bath Journal, 2 December $1805,3$. 
was performed as a part of the oratorio season at the Theatre Royal, Covent Garden, on 19 March 1806. ${ }^{51}$ Unfortunately, Rauzzini’s music does not appear to have been published, and no manuscript has been discovered.

The conditions that faced foreign-born musicians in Britain during a time of war could be challenging because of economic belttightening and latent xenophobia. Rauzzini's situation as a castrato in a leadership capacity further invited a level of distrust that was based on fears about the negative impact of the castrato on society that dated back to the early years of the century. In spite of the negativity emanating from some quarters, Rauzzini continued to make significant contributions to British culture. He proved himself sensitive to the changing cultural and political dynamics of the times, adapting the repertoire of his concerts as necessary, while still maintaining their artistic integrity. At the time of his death in 1810, Rauzzini was eulogized in highly complimentary terms. The Bath Chronicle wrote that: "In private life few men were more esteemed; none more generally beloved. A polished suavity of manners, a mild and cheerful disposition, and a copious fund of general and polite information, rendered him an attractive and agreeable companion." 52 Rauzzini was given a public funeral at the Bath Abbey, and the Bath Journal records that the city had not "witnessed a funeral so well attended since the days of [Beau] Nash." ${ }^{3}$ Although a Catholic, Rauzzini was buried at the Bath Abbey where a plaque erected by two of his most famous students, Nancy Storace and John Braham, can be found. This memorial speaks eloquently to Rauzzini's success as a teacher, musician and cultural leader in Britain-a success that he achieved in spite of being foreignborn and socially "other."

51. The Times [London], 11 March 1806, 3.

52. Bath Chronicle, 12 April 1810, 3.

53. Bath Journal, 16 April 1810, 3. 